\title{
Pengaruh Model Pembelajaran Berbasis Masalah Dengan Pendekatan CPS Terhadap Kemampuan Berpikir Kreatif Siswa SMP Ditinjau Dari Self Efficacy
}

\author{
(The Effect Of Problems Based Learning Model With CPS Approach To The Creative
} Thinking Students' Abilities Against Of Junior High School In Terms Of Self Efficacy)

\author{
Nurfitriani $^{1}$, Fahinu $^{2}$, Mukhsar $^{3}$ \\ ${ }^{1}$ Alumnus Prodi Pendidikan Matematika PPs Universitas Halu Oleo \\ ${ }^{2}$ Dosen Pendidikan Matematika FKIP dan PPs Universitas Halu Oleo; Co-author: fahinu@uho.ac.id \\ ${ }^{3}$ Dosen FMIPA dan Pendidikan Matematika PPs Universitas Halu Oleo
}

\begin{abstract}
Abstrak: Penelitian ini bertujuan untuk menyelidiki efek Pembelajaran Berbasis Masalah dengan pendekatan CPS terhadap kemampuan berpikir kreati matematik siswa ditinjau dari Self-Efficacy. Subyek penelitian ini adalah 43 siswa kelas VII SMP Negeri 2 Baubau tahun pelajaran 2016/2017. Desain penelitian yang digunakan dalam penelitian ini adalah pretest- posttest control group design. Dua dari enam belas diambil dengan teknik purposive sampling. Kemudian dipilih secara acak satu kelas sebagai kelas eksperimen yang mengikuti pembelajaran berbasis masalah dengan pendekatan CPS, dan satu kelas lainnya sebagai kelompok kontrol yang mengikuti pembelajaran langsung. Self Efficacy siswa diukur dengan angket Self-Efficacy dan kemampuan berpikir kreatif diukur dengan menggunakan tes kemampuan berpikir kreatif yang diberikan saat pre-test dan posttest. Data dianalisis dengan menggunakan statistik deskriptif dan statistik inferensial dengan uji hipotesis menggunakan ANAVA satu jalur, ANAVA dua jalur, dan Uji t pada $\alpha=0,05$. Hasil penelitian menunjukkan bahwa kemampuan berpikir kreatif matematik siswa yang diajar dengan model pembelajaran berbasis masalah dengan pendekatan CPS lebaik baik daripada kemampuan berpikir kreatif matematik siswa yang diajar dengan model pembelajaran langsung ditinjau dari Self-Efficacy.
\end{abstract}

Kata kunci: Kemampuan berpikir kreatif matematik, Self-Efficacy, model pembelajaran berbasis masalah, pendekatan CPS

\begin{abstract}
This study aimed to investigate the effect of Problem-based learning approach to CPS against mathematical kreati thinking ability of students in terms of Self-Efficacy. The subject of the study was 43 grade VII SMP Negeri 2 Baubau years lessons 2016/2017. The research design used in this study is a pretest-posttest control group design. Two of the sixteen taken with purposive sampling technique. Then randomly selected a class as a class experiment that follows the learning-based approach to problems with CPS, and one other class as a control group who follow learning directly. Self Efficacy of students as measured by the now Self-Efficacy and creative thinking ability is measured by using the test the ability of the creative thinking that given the time of pre-and post test-test. The data were analyzed using descriptive statistics and statistical hypothesis testing with inferensial ANAVA uses one line, two lines of ANAVA, and t Test on $\alpha=$ 0.05 . The results showed that the ability of mathematical creative thinking of students taught with model-based learning problems with the approach of the CPS lebaik better than the creative thinking ability of the students taught with mathematical models of learning directly in terms of Self-Efficacy
\end{abstract}

Keywords: The Ability Of Mathematical Creative Thinking, Self-Efficacy, Problem-Based Learning Model, CPS Approach.

\section{PENDAHULUAN}

Matematika merupakan ilmu yang menjelaskan konsep mulai dari yang abstrak, hingga yang terdefinisi dengan jelas. Hal ini karena matematika bukan berasal dari pengamatan, melainkan dari ide-ide, proses, dan pembuktian deduktif.
Karena itu, banyak kemampuan berpikir matematika tingkat tinggi yang dapat dikembangkan saat mempelajari matematika. Terdapat berbagai macam kemampuan berpikir matematika tingkat 
tinggi, salah satunya kemampuan berpikir kreatif matematik siswa.

Kemampuan berpikir matematika tingkat tinggi siswa Indonesia dapat digolongkan rendah. Hal ini terlihat dari hasil survei internasional PISA dan TIMSS. Pada PISA tahun 2015, Indonesia berada diperingkat 68 dari 76 peserta PISA. Prestasi pada TIMSS (Trends in International Mathematics and Science Study) 2015, Indonesia berada pada peringkat 36 dari 49 peserta TIMSS. Hasil survei ini menunjukkan bahwa mayoritas siswa Indonesia belum mampu mengembangkan ide dan pemikirannya dalam menyelesaikan masalah matematika. Hal ini menunjukkan bahwa KBKM siswa juga masih rendah.

Berdasarkan hasil wawancara dengan salah satu guru matematika di SMP Negeri 2 Baubau pada observasi awal diperoleh informasi bahwa pembelajaran yang berlangsung di SMP Negeri 2 Baubau khususnya pelajaran matematika yaitu masih pembelajarannya yang berpusat pada guru. Padahal seperti kita ketahui bahwa pembelajaran yang berpusat pada guru merupakan salah satu penyebab rendahnya KBKM. Karena pembelajaran yang berpusat pada guru cenderung menjelaskan sesuai materi yang ada tanpa melibatkan interaksi peserta didik atas pendapat dan analisanya sehingga mengakibatkan siswa tidak mampu mengungkapkan ide kreatif untuk solusi masalah tersebut dan akan menyerah begitu saja. Sikap mudah menyerah menunjukkan Self-Efficacy yang rendah. Strecher, dkk dalam Noer (2012) mengatakan bahwa Self-Efficacy juga mempengaruhi pilihan seseorang dalam pengaturan perilaku, banyaknya usaha mereka untuk menyelesaikan tugas, dan lamanya waktu mereka bertahan dalam menghadapi hambatan. Akhirnya, SelfEfficacy mempengaruhi reaksi emosional seseorang, seperti kecemasan dan kesusahan, dan pola pikir. Dengan demikian, individu dengan Self-Efficacy rendah terhadap tugas tertentu lebih berpikir tentang kekurangan pribadi mereka daripada berpikir tentang menyelesaikan tugas, pada gilirannya akan menghambat kinerja keberhasilan menyelesaikan tugas.

Hal ini menunjukkan perlu ada inovasi pembelajaran yang di- terapkan yang dapat meningktakan kemampuan berpikir kreatif matematik. Pembelajaran berbasis masalah merupakan salah satu alternatif untuk meningkatkan kemampuan berpikir kreatif matematik. Tan dalam Rusman (2010: 229) Pembelajaran Berbasis masalah merupakan inovasi dalam pembelajaran karena PBM kemampuan berpikir siswa betul-betul dioptimalkan melalui proses kerja kelompok atau tim yang sistematis, sehingga siswa dapat memberdayakan, mengasah, menguji, dan mengembangkan kemampuan berpikirnya secara berkesinambungan.

Selain model pembelajaran yang harus diperhatikan, dirasa perlu juga untuk menerapkan suatu pendekatan pembelajaran yang memberi peluang bagi siswa untuk mengkontruksikan kemampuan kognitif mandiri dan proses pembelajarannya berorientasi pada proses pemecahan masalah secara kreatif kolaboratif. Salah satu alternative pendekatan pembelajaran yang member peluang bagi siswa untuk mengkontruksikan pengetahuan mereka serta berorientasi pada proses pemecahan masalah secara kreatif adalah pendekatan CPS. CPS merupakan suatu pendekatan pembelajaran yang melakukan pemusatan pada pengajaran dan keterampilan pemecahan masalah yang diikuti dengan penguatan ketrampilan (Pepkin, 2004:1). Dengan pendekatan ini diharapkan ketika dihadapkan dengan suatu masalah, siswa dapat melakukan keterampilan memecahkan masalah dan mengembangkan ide-idenya. Hal ini 
dilakukan tidak hanya dengan cara menghafal tanpa dipikir, tetapi lebih pada ketrampilan pemahaman dan pemecahan masalah serta memperluas proses berpikir. Dengan demikian diharapkan siswa akan merasa tertarik dan tertantang untuk terus mencoba menyelesaikan masalah-masalah

\section{METODE PENELITIAN}

Jenis penelitian ini merupakan penelitian Quasi Experiment yang merupakan pengembangan dari True Experiment dengan menggunakan pretest posttest control group design. Penelitian ini akan dilaksanakan di SMP Negeri 2 Baubau pada semester genap pada Tahun Pelajaran 2016/2017.

Penelitian ini melibatkan tiga variabel yang terdiri dari variabel bebas (independent), variabel terikat (dependent) dan variabel moderat. Variabel bebas dalam penelitian ini adalah model pembelajaran yang terdiri atas model pembelajaran berbasis masalah dengan pendekatan CPS dan model pembelajaran langsung, variabel terikat dalam penelitian ini adalah kemampuan berpikir kreatif matematik siswa, dan yang menjadi variabel moderat dalam penelitian ini adalah Self-Efficacy siswa terhadap matematika.

Populasi penelitian yaitu siswa kelas VII SMP Negeri 2 Baubau, dimana kelas tersebut terdiri dari 16 kelas paralel. Sampel diambil berdasarkan teknik pengambilan purposive sampling

\section{HASIL PENELITIAN}

Rata-rata Self-Efficacy siswa pada kelas eksperimen sebesar 103,33 dengan Median sebesar 105,48 serta Standar deviasi sebesar 13,30. Rata-rata SelfEfficacy siswa pada kelas kontrol sebesar 108,99 dengan Median sebesar 110,41 serta Standar deviasi sebesar 12,42

Berdasarkan kategori Self-Efficacy untuk kelas eksperimen, yaitu kategori Self-Efficacy tinggi sebanyak 3 orang atau $14,3 \%$ dengan rata-rata sebesar 124,14 , matematika yang ada sehingga terbiasa berfikir kreatif dalam mengembangkan ide-ide yang dimilikinya pada saat memecahkan masalah-masalah matematika.

kemudian untuk memilih kelas eksperimen dan kelas kontrol digunakan random kelas yaitu, satu kelas ekperimen dan satu kelas kontrol.

Data dalam penelitian ini diperoleh dari hasil tes kemampuan berpikir kreatif matematik untuk mengukur kemampuan kemampuan berpikir kreatif matematik dan non tes yang diberikan berupa angket untuk mengukur Self-Efficacy siswa, serta dari lembar obrservasi pengamatan pembelajaran.

Statistik deskriptif digunakan untuk mendeskripsikan nilai yang diperoleh masing-masing kelas dalam bentuk ratarata, nilai maksimum, nilai minimum dan standar deviasi. Analisis inferensial dalam penelitian ini digunakan untuk menguji hipotesis penelitian, namun terlebih dahulu melalui tahapan uji yang lain, yaitu uji normalitas dan uji homogenitas sebagai uji prasyarat untuk melakukan uji hipotesis. Data yang digunakan dalam uji normalitas, ANAVA satu jalur, Regresion Linear dan uji-t berbentuk skor Normalized Gain (N-gain).

sedang sebanyak 15 orang atau $71,4 \%$ dengan rata-rata 103,12 dan kategori rendah sebanyak 3 orang atau 14,3\% dengan rata-rata 83,57. Kelas kontrol kategori Self-Efficacy tinggi sebanyak 2 orang atau $9,1 \%$ dengan rata-rata sebesar 132,66 , sedang sebanyak 16 orang atau $72,7 \%$ dengan rata-rata 110,55 dan kategori rendah sebanyak 4 orang atau $18,2 \%$ dengan rata-rata 90,92. 
Berdasarkan aspek-aspek dalam Self-Efficacy untuk kelas eksperimen, aspek keyakinan diri siswa yang paling tinggi yaitu aspek kekuatan keyakinan (strength) yaitu sebesar 76,53\%. Kemudian disusul aspek generalitas (generality) yaitu sebesar 75,91\%. Sedangkan aspek yang keyakinan diri siswa pada kelas eksperimen yang paling rendah yaitu pada aspek tingkat kesulitan tugas (magnitude) sebesar $72,71 \%$. Pada kelas kontrol, aspek keyakinan diri siswa yang paling tinggi yaitu aspek generalitas (generality) yaitu sebesar 76,13\%. Kemudian disusul aspek kekuatan keyakinan (strength) yaitu sebesar 69,84\%. Sedangkan aspek yang keyakinan diri siswa pada kelas kontrol yang paling rendah yaitu pada aspek tingkat kesulitan tugas (magnitude) sebesar 69,64\%.

Peningkatan rataan kemampuan berpikir kreatif matematik siswa pada kelas eksperimen yang diberi perlakuan model pembelajaran berbasis masalah dengan pendekatan CPS lebih tinggi ketimbang peningkatan rataan kemampuan berpikir kreatif matematik siswa siswa pada kelas kontrol yang diberi perlakuan model pembelajaran langsung. Pada siswa kelas eksperimen kemampuan berpikir kreatif matematik siswa meningkat dari 26,11 pada pretest menjadi 47,47 pada posttest. Sedangkan pada kelas kontrol kemampuan berpikir kreatif matematik siswa meningkat dari 25,49 pada pretest menjadi 37,50 pada posttest. Rata-rata NGain kemampuan berpikir kreatif matematik siswa pada kelas eksperimen adalah 0,29 dengan standar deviasi sebesar 0,35 . Rata-rata N-Gain kemampuan berpikir kreatif matematik siswa pada kelas kontrol adalah 0,17 dengan standar deviasi sebesar 0,097.

Berdasarkan kategori, pada kategori Self-Efficacy tinggi rataan N-Gain kemampuan berpikir kreatif matematik siswa yang diajar dengan model pembelajaran berbasis masalah dengan pendekatan CPS sebesar 0,41 dengan standar deviasi sebesar 0,12 , rataan $\mathrm{N}$ Gain kemampuan berpikir kreatif matematik siswa yang diajar dengan model pembelajaran langsung sebesar 0,15 dengan standar deviasi sebesar 0,12 . Pada kategori Self-Efficacy sedang rataan N-Gain kemampuan berpikir kreatif matematik siswa yang diajar dengan model pembelajaran berbasis masalah dengan pendekatan CPS sebesar 0,27 dengan standar deviasi sebesar 0,11 , rataan $\mathrm{N}$-Gain kemampuan berpikir kreatif matematik siswa yang diajar dengan model pembelajaran langsung sebesar 0,17 dengan standar deviasi sebesar 0,08. Pada kategori Self-Efficacy rendah rataan $\mathrm{N}$-Gain kemampuan berpikir kreatif matematik siswa yang diajar dengan model pembelajaran berbasis masalah dengan pendekatan CPS sebesar 0,26 dengan standar deviasi sebesar 0,14 , rataan $\mathrm{N}$-Gain kemampuan berpikir kreatif matematik siswa yang diajar dengan model pembelajaran langsung sebesar 0,14 dengan standar deviasi sebesar 0,14.

Berdasarkan dari keempat aspek kemampuan berpikir kreatif matematik siswa pada siswa kelas eksperimen yang paling meningkat adalah aspek elaborasi yaitu sebesar $26,78 \%$ peningkatannya. Pada siswa kelas kontrol aspek kemampuan berpikir kreatif yang paling meningkat adalah aspek elaborasi yaitu sebesar 22,15\%. Sedangkan aspek kemampuan berpikir kreatif matematik siswa yang paling rendah peningkatannya pada kelas eksperimen adalah aspek fleksibel yaitu sebesar $18,75 \%$, begitupun pada kelas kontrol aspek kemampuan berpikir kreatif matematik siswa yang paling rendah peningkatannya pada kelas kontrol adalah aspek fleksibel yaitu sebesar 5,39\%.

Hasil pengamatan proses pembelajaran dari enam kali pertemuan hasil observasi dapat dideskripsikan bahwa proses pembelajaran dengan 
menggunakan model pembelajaran berbasis masalah dengan pendekatan CPS secara keseluruhan dapat dikategorikan baik. Begitupun proses pembelajaran dengan menggunakan model pembelajaran langsung secara keseluruhan dapat dikategorikan baik. Hal ini terlihat dari skor keseluruhan persentase aktifitas pembelajaran mencapai kategori baik.

Berdasarkan hasil analisis uji prasyarat menunjukkan bahwa data kedua kelompok pembelajaran mempunyai sampel yang berasal dari populasi yang berdistribusi normal dan memiliki varians yang homogen.

Berdasarkan hasil analisis menggunakan uji ANAVA satu jalur menggunakan SPSS 21 diperoleh bahwa nilai $\mathrm{F}=13,631$ dengan Sig. $=0,01$. Karena sig. $<\alpha=0,05$, maka $\mathrm{H}_{0}$ ditolak. Dengan ditolaknya $\mathrm{H}_{0}$ ditolak berarti terdapat perbedaan rata-rata kemampuan berpikir kreatif matematik siswa antara siswa yang diajar dengan model pembelajaran berbasis masalah dengan pendekatan CPS dengan siswa yang diajar dengan model pembelajaran langsung.

Hasil analisis menggunakan uji ANAVA dua jalur menggunakan SPSS 21 diperoleh bahwa nilai $\mathrm{F}=5,907$ dengan dengan Sig. $=0,006$. Karena Sig. $<\alpha=$ 0,05 , maka $\mathrm{H}_{0}$ ditolak. Dengan ditolaknya $\mathrm{H}_{0}$ maka dapat disimpulkan bahwa ada pengaruh yang signifikan model pembelajaran berbasis masalah dengan pendekatan CPS dan model pembelajaran langsung terhadap peningkatan kemampuan berpikir kreatif matematik siswa ditinjau dari Self-Efficacy. Tampak dari hasil analisis bahwa pengaruh model pembelajaran, Self-Efficacy, dan interaksi antara model pembelajaran dengan SelfEfficacy terhadap kemampuan berpikir kreatif matematik sebesar 55,70\%.

Hasil analisis untuk melihat pengaruh model pembelajaran berbasis masalah dengan pendekatan CPS dan model pembelajaran langsung terhadap peningkatan kemampuan berpikir kreatif matematik siswa ditinjau dari masingmasing kategori Self-Efficacy menggunakan uji Independent Samples Test menggunakan SPSS 21 pada kategori Self-Efficacy tinggi, diperoleh nilai $t_{\text {hitung }}$ $=0,971$ dengan Sig/2. $=0,403 / 2=0,215$. Karena $t_{\text {hitung }}=0,971<t_{(0,025 ; 3)}=$ 3,182 dan $\mathrm{Sig} / 2 \geq \alpha=0,05$, maka $\mathrm{H}_{0}$ diterima. Dengan diterimanya $\mathrm{H}_{0}$ maka dapat disimpulkan bahwa secara signifikan peningkatan kemampuan berpikir kreatif matematik siswa yang diajar dengan model pembelajaran berbasis masalah dengan pendekatan CPS relatif sama atau lebih rendah daripada siswa yang diajarkan model pembelajaran langsung pada siswa dengan Self-Efficacy tinggi.

Pada kategori Self-Efficacy sedang diperoleh nilai $t_{\text {hitung }}=2,517$ dengan Sig. $/ 2=0,006 / 2=0,003$. Karena $t_{\text {hitung }}=$ $2,517>t_{(0,025 ; 28)}=2,048$ dan sig. $/ 2<\alpha$ $=0,05$, maka $\mathrm{H}_{0}$ ditolak. Dengan ditolaknya $\mathrm{H}_{0}$ maka dapat disimpulkan bahwa secara signifikan peningkatan kemampuan berpikir kreatif matematik siswa yang diajar dengan model pembelajaran berbasis masalah dengan pendekatan CPS lebih tinggi dibandingkan siswa yang diajarkan model pembelajaran langsung pada siswa dengan Self-Efficacy sedang.

Pada kategori Self-Efficacy rendah diperoleh nilai $t_{\text {hitung }}=2,664$ dengan Sig. $/ 2=0,045 / 2=0,0023$. Karena $t_{\text {hitung }}=$ $2,664>t_{(0,025 ; 5)}=2,570$ dan sig. $/ 2<\alpha$ $=0,05$, maka $\mathrm{H}_{0}$ ditolak. Dengan ditolaknya $\mathrm{H}_{0}$ maka dapat disimpulkan bahwa secara signifikan peningkatan KBKM siswa yang diajar dengan model pembelajaran berbasis masalah dengan pendekatan CPS lebih tinggi dibandingkan siswa yang diajarkan model pembelajaran langsung pada siswa dengan Self-Efficacy rendah. 


\section{PEMBAHASAN}

Hasil analisis data baik dari analisis deskriptif maupun analisis inferensial menunjukan bahwa adanya peningkatan KBKM pada masing-masing kelas yaitu kelas eksperimen dan kelas kontrol.

Secara keseluruhan dari hasil analisis diperoleh bahwa semakin tinggi Self-Efficacy juga berpengaruh terhadap tingginya KBKM siswa. dan semakin rendah Self-Efficacy siswa maka KBKM siswa semakin rendah. Hal ini didukung pendapat yang dikemukakan oleh Prastiyo (2008) bahwa ada hubungan positif antara kepercayaan diri dengan prestasi belajar. Hasil analisis juga menyimpulkan model pembelajaran berbasis masalah dengan pendekatan CPS mempunyai pengaruh terhadap peningkatan KBKM siswa . Adanya peningkatan tersebut, membuktikan bahwa model pembelajaran berbasis masalah dengan pendekatan CPS berpengaruh terhadap KBKM siswa. Hal ini sesuai dengan hasil penelitian Sohibi (2012) bahwa model pembelajaran berbasis masalah dan inkuiri memberikan pengaruh lebih baik terhadap kemampuan berpikir kritis dan kreatif siswa.

\section{KESIMPULAN DAN SARAN}

Berdasarkan hasil penelitian dan pembahasan, maka kesimpulan dalam penelitian ini adalah sebagai berikut.

1. Secara deskriptif kemampuan berpikir kreatif matematik siswa yang diajar dengan model pembelajaran berbasis masalah dengan pendekatan CPS lebih tinggi daripada kemampuan berpikir kreatif matematik siswa yang diajar dengan model pembelajaran langsung ini dapat dilihat dari nilai rata-rata $\mathrm{N}$ Gain.

2. Ada perbedaan pengaruh yang signifikan antara model pembelajaran berbasis masalah dengan pendekatan CPS dan model pembelajaran langsung terhadap peningkatan kemampuan
Tetapi harus diakui bahwa peningkatan KBKM yang dicapai siswa dalam penelitian ini kurang maksimal. Hal ini bisa terlihat dari perbandingan skor rata-rata antara kelas yang diajarkan dengan model pembelajaran berbasis masalah dengan pendekatan CPS dan kelas yang diajarkan dengan pembelajaran langsung tidak terlalu tinggi malahan hampir sama. Hal ini disebabkan keterbatasan waktu, serta siswa belum terbiasa dengan kegiatan pemecahan masalah. Hal ini sesuai yang disampaikan Wina Sanjaya, bahwa kelemahan strategi berbasis masalah antara lain: 1). Keberhasilan strategi berbasis masalah membutuhkan cukup waktu, dan 2). Manakala siswa tidak memiliki minat atau tidak mempunyai kepercayaan tentang masalah yang dipelajari, maka siswa merasa enggan untuk mencoba.

Dari hasil penelitian ini dapat dijadikan acuan bagi para guru untuk melaksanakan pembelajaran dengan menggunakan model pembelajaran berbasis masalah dengan pendekatan CPS yang dapat meningkatkan kemampuan berpikir kreatif matematik.

berpikir kreatif matematik siswa. kemampuan berpikir kreatif matematik siswa yang diajar dengan penerapan model pembelajaran berbasis masalah dengan pendekatan CPS lebih baik daripada kemampuan berpikir kreatif matematik siswa yang diajar dengan model pembelajaran langsung.

3. Ada perbedaan pengaruh yang signifikan antara model pembelajaran berbasis masalah dengan pendekatan CPS dan model pembelajaran langsung terhadap peningkatan kemampuan berpikir kreatif matematik siswa. kemampuan berpikir kreatif matematik siswa yang diajar dengan penerapan model pembelajaran berbasis masalah 
dengan pendekatan CPS lebih baik daripada kemampuan berpikir kreatif matematik siswa yang diajar dengan model pembelajaran langsung ditinjau dari Self-Efficacy.

4. Ada pengaruh yang tidak signifikan model pembelajaran berbasis masalah dengan pendekatan CPS dan model pembelajaran langsung terhadap peningkatan kemampuan berpikir kreatif matematik siswa pada siswa dengan Self-Efficacy tinggi.

5. Ada pengaruh yang signifikan model pembelajaran berbasis masalah dengan pendekatan CPS dan model pembelajaran langsung terhadap peningkatan kemampuan berpikir kreatif matematik siswa pada siswa dengan Self-Efficacy sedang.

6. Ada pengaruh yang signifikan model pembelajaran berbasis masalah dengan pendekatan CPS dan model pembelajaran langsung terhadap peningkatan kemampuan berpikir kreatif matematik siswa pada siswa dengan Self-Efficacy rendah.

Berdasarkan kesimpulan yang telah dipaparkan, maka peneliti menyarankan beberapa hal berikut .

1. Guru hendaknya melakukan menerapkan model pembelajaran berbasis masalah dengan pendekatan

\section{DAFTAR PUSTAKA}

Bandura, A. 1997. Self Efficacy : The Exercise Of Control. New York : W.H. Freeman and Company. [Online]. Tersedia: https://www.amazon.com/SelfEfficacy-Exercise-Control-AlbertBandura/dp/0716728508. Oktober 2016]

Beyer, B .K. 1991. Teaching Thinking Skills: A Handbook for Elementary School Teachers. Boston: Allyn \& Bacon.
CPS sebagai alternatif pembelajaran di kelas sehingga siswa tidak mudah bosan dan termotivasi untuk mengikuti pelajaran.

2. Perlunya dikembangkan bahan ajar berbasis masalah dengan pendekatan CPS sehingga bisa diaplikasikan dan digunakan oleh guru pada materi-materi matematika yang lain dengan menggunakan pembelajaran berbasis masalah dengan pendekatan CPS.

3. Bagi peneliti lanjut, hasil penelitian model pembelajaran berbasis masalah dengan pendekatan CPS diharapkan dapat dijadikan landasan untuk penelitian selanjutnya untuk materi lain, sehingga dapat dijadikan sebagai bahan pertimbangan guru bidang studi untuk menerapkan model dan teknik pembelajaran di sekolah yang bersangkutan.

4. Beberapa hal yang perlu menjadi perhatian bagi peneliti selanjutnya yaitu, minat atau kepercayaan siswa, waktu persiapan dan juga pemahaman siswa tentang mengapa mereka perlu berusaha memecahkan masalah. Karena tanpa beberapa hal tersebut siswa akan enggan mencoba memecahkan masalah yang sedang dipelajari.

Djarwanto. 2003. Statistik Non Parametrik. Yogyakarta. BPFE Yogyakarta.

Eagly, A. H, \& Chaiken, S. 1993. The psychology of attitudes. Fort Worth, TX: Harcourt Brace Jovanovich College Publishers.

Eggen \& Kauchak. 2012. Strategi dan Model pembelajaran: Mengajarkan konten dan keterampilan berpikir. Terjemahan Satrio Wahono Baston (Buku asli terbitan tahun 2012). 
Filsaime, K. D. 2008. Menguak Rahasia Berpikir Kritis dan Kreatif. Jakarta: Prestasi Pustakarya.

Fisher, R. 1995. Teaching Children to Think. Cheltenham: Stanley Thornes Ltd.

Ibrahim, M. \& Nur. 2000. Pengajaran Berdasarkan Masalah. Surabaya: University Press Marianty A.

Ismaimuza, D. 2010. Kemampuan Berpikir kritis dan Kreatif Matematis Siswa SMP melalui Pembelajaran Berbasis Masalah dengan Strategi Konflik Kognitif. Disertasi Doktor pada SPS UPI: Tidak diterbitkan.

Munandar, U. 2009. Pengembangan Kreativitas Anak Berbakat. Jakarta : Rineka Cipta.

Noer, H. S. 2012. Self-Efficacy Mahasiswa Terhadap Matematika. Seminar Nasional Matematika dan Pendidikan Matematika FMIPA UNY; November 2012. ISBN : 978979-16353-8-7

Pepkin, K. 2000. Creative Problem Solving in Math. [Online]. Tersedia: www.artofproblemsolving.com. [17 Oktober 2016].

Sohibi, M. 2012. Pengaruh Pembelajaran Berbasis Masalah dan Inkuiri Terbimbing terhadap kemampuan berpikir kritis dan kreatif siswa. $E$ journal. Prodi Pendidikan Fisika IKIP PGRI Semarang.

Tan, O. S. 2003. Problem-based learning innovation: Using problems to power learning in the 21 st century. Singapore: Thomson Learning. [Online]. Tersedia: http://www.tp.edu.sg/staticfiles/TP/fi les/centres/pbl/pbl._tan_oon_seng.p df. [20 oktober 2016]. 